конференції, присвяченої 210-річчю з дня заснування Харківського національного педагогічного університету імені Г. С. Сковороди / за загальною редакцією акад. Прокопенка І. Ф. Харків, 2014. С. 417-421.

5. Сучасні технології збереження здоров'я учнів: кращий досвід / авт. кол. ; уклад. А. Г. Обухівська. Київ, $2015.221 \mathrm{c}$.

\section{REFERENCES}

1. Entsyklopediia osvity (2008). [Encyclopedia of education]. (ed.).V. H. Kremen. Kyiv, 1040 p. [in Ukrainian].

2. Zakon Ukrainy "Pro osvitu" (2014). [The law of Ukraine "About education"]. Available at: https:// ru.osvita.ua/legislation/law/2231/ [in Ukrainian].

3. Zamrozevych-Shadrina, S. (2014). Problemy zberezhennia ta zmitsnennia zdorovia ditei doshkilnoho viku [The problems of preservation and strengthening of health of preschool children]. Obrii. No. 2(39), pp. 12-14. [in Ukrainian].
4. Pohribniak, N. V. \& Yeremieieva, M. Ye. (2014). Zberezhennia fizychnoho i psykhichnoho zdorovia ditei doshkilnoho viku zasobamy art-terapii [The preserving of physical and mental health of preschool children by means of art therapy]. Pedahohika zdorovia : zbirnyk naukovykh prats IV Vseukrainskoi naukovo-praktychnoi konferentsii, prysviachenoi 210-richchiu z dnia zasnuvannia Kharkivskoho natsionalnoho pedahohichnoho universytetu imeni H. S. Skovorody - The education of health: scientific papers of the 4-th All-Ukrainian ScientificPractical Conference devoted to the 210-th anniversary of the founding of the G. S. Skovoroda Kharkiv National Pedagogical University. (pp. $417-$ 421). Kharkiv. [in Ukrainian].

5. Suchasni tekhnolohii zberezhennia zdorovia uchniv: krashchyi dosvid (2015). [Modern technologies of health students: best practices]. (Ed.). A. H. Obukhivska. Kyiv, 221 p. [in Ukrainian].

Стаття надійшла до редакції 28.03.2019

УДК 378.147.091.31-051:5

DOI:

Олена Блашкова, аспірант кафедри педагогіки та управління навчальним закладом Кам'янеиь-Подільського начіонального університету імені Івана Огієнка

\title{
КЛЮЧОВІ КОМПЕТЕНТНОСТІ МАЙБУТНІХ ВЧИТЕЛІВ ПРИРОДНИЧИХ СПЕЦАЛЬНОСТЕЙ ТА ЇХ ВПЛИВ НА ФОРМУВАННЯ СВІТОГЛЯДНИХ ОРІЕНТИРІВ СУЧАСНОЇ СТУДЕНТСЬКОЇ МОЛОДІ
}

У статті висвітлено пріоритетні компетентності майбутніх вчителів природничих спеціальностей та їх вплив на формування світоглядних орієнтирів сучасної студентської молоді. Акиентується увага на змісті ключових фахових компетентностей першого (бакалаврського) та другого (магістерського) рівнів підготовки студентів природничих специіальностей. Підкреслено, щ̧о формування гуманістичних иінностей $\epsilon$ важливим процесом становлення майбутніх учителів, як професіоналів.

Ключові слова: майбутні вчителі природничих спещіальностей; гуманістичні ціннісні орієнтири; ключові компетентності.

Лim. 13.

Olena Blaskova, Postgraduate Student of the Pedagogy and Management of Educational Institution Department Kamyanets-Podilskiy Ivan Ohiyenko National University

\section{KEY COMPETENCIES OF FUTURE TEACHERS OF NATURAL SCIENCES AND THEIR INFLUENCE ON THE FORMATION OF IDEOLOGICAL LANDMARKS OF MODERN STUDENTYOUTH}

Formulation of the problem. The article highlights the priority of special-subject competencies of the professional training of future teachers of natural sciences and the possibility of forming humanistic values during the educational process.

The relevance of the chosen theme is based on the fact that in the present time the reform of the pedagogical education of higher educational institutions and the implementation of the course of humanization and humanization of the educational process, based on personality-oriented, axiological, humanistic and competent approaches, contributes to the formation of humanistic values in the process of professional development of future teachers.

The purpose of the paper is to update the natural and ecological competencies in the process of forming humanistic values of the modern student youth of natural sciences.

Research methods. The search materials for writing the article were scientific articles, normative documents, educational-professional programs and curricula of specialties 014 Secondary education (Biology and human health); 014 Secondary education (Geography) and 101 "Ecology" of preparation of the first (Bachelor) and 


\section{КЛЮЧОВІ КОМПЕТЕНТНОСТІМАЙБУТНІХ ВЧИТЕЛІВПРИРОДНИЧИХ СПЕЦІАЛЬНОСТЕЙ ТАЇХ ВПЛИВ НА ФОРМУВАННЯ СВІТОГЛЯДНИХ ОРІЕНТИРІВ СУЧАСНОӤ СТУДЕНТСЬКОӤ МОЛОДІ}

second (master's) levels of higher education, scientific-pedagogical manuals and textbooks on the studied issues. In the process of research we used the search-bibliographic method; as well as general scientific methods of analysis, synthesis, classification, systematization and generalization of the results of the research.

Main results of the study. On the basis of the received materials of the conducted research the possibility of the formation of humanistic values of landmarks as components of the outlook of the future teachers of natural sciences, during their mastering by special-subject professional competencies has been identified.

Conclusions and specific suggestions of the author. It is emphasized on the necessity of determining the significance of priority the special-subject competencies in the process of forming the humane outlook of contemporary student youth. As such an approach enables the personal development and professional formation of future teachers of natural sciences, as well as the formation of their own humane values, which will promote the implementation of appropriate humanistic-oriented behavior.

Keywords: student youth; humanistic values; key competencies.

П остановка проблеми. Сучасні реформи, гуманітарні та природничі досягнення, які пропонує вища освіта в процесі фахової підготовки студентів потребують постійного розвитку та доповнення їх фахових професійних компетентностей. В основі підготовки спеціалістів педагогічної освіти України покладено низку підходів, зокрема особистісноорієнтований, гуманістичний, аксіологічний та компетентнісний. Цілком очевидно, зростають вимоги і до особистісного розвитку майбутніх педагогів. Науковці обгрунтовують доцільність введення до змісту професійної педагогічної компетентності низки особистісних та мотиваційних характеристик педагога, що визначатимуть ефективність його професійної діяльності та сприятимуть неперервному саморозвитку. Оскільки суб'єктами нашого дослідження виступають майбутні вчителі природничих спеціальностей, тому вважаємо, що важливим $є$ безперечно, формування у них ключових фахових спеціально-предметних компетентностей, які сприяють більш якісному та ефективному становленню гуманістичного світогляду сучасної студентської молоді.

Система фахових компетентностей підготовки студентів природничих спеціальностей педагогічної освіти та виховання студентів висвітлені у Законі України “Про освіту", освітньо-професійних програмах підготовки першого (бакалаврського) та другого (магістерського) рівнів вищої освіти природничих спеціальностей Кам'янець-Подільського національного університету імені Івана Огієнка.

Аналіз останніх досліджень і публікацій. Проаналізувавши сучасні наукові дослідження педагогічної сфери, стало відомо, що більшість питань науковців токраються загальних аспектів компетентнісного підходу: Т. Байбара, Н. Бібік, Л. Ващенко, О. Пометун, Г. Терещук. Дослідженням теорій формування ціннісних орієнтацій займалися I. Бех, Е. Ільенков, М. Каган, І. Кучинська. Аналіз педагогічних умов формування професійної компетентності студентів вивчають
О. Бондаревська, Н. Борисенко, І. Зязюн, Ю. Лінник та ін.

Постановка завдання. Актуальність проблеми полягає у висвітлені наявності та доцільності пріоритетних природознавчих та екологічних компетентностей, як важілів професійного становлення та особистісного розвитку майбутніх вчителів природничих спеціальностей в контексті засвоєння фахових компетентностей. На нашу думку, оволодіння природознавчими та екологічними компетентностями розкриє додаткові можливості для глибшого розуміння студентами, важливості формування у них, власних ціннісних гуманістичних орієнтирів.

Мета статті полягає у актуалізації природознавчих та екологічних компетентностей у процесі формування гуманістичних ціннісних орієнтирів сучасної студентської молоді природничих спеціальностей.

Виклад основного матеріалу. Сучасні орієнтири української освіти наєвропейські цінності вимагають відповідних змін у професійній підготовці спеціалістів, зокрема педагогів. Сьогодні потрібні не лише вузько кваліфіковані професіонали, які досконало володіють набутими професійними знаннями, вміннями та навичками, а й конкурентоспроможні особистості, здатні до постійного самовдосконалення та розвитку, відповідальні за власні рішення, які здатні вирішувати будь яку ситуацію, активні, діючі особистості, що реалізовують власний потенціал для розвитку держави. 3 огляду на планетарну екологічну кризу, що склалася внаслідок життєдіяльності людини, вважаємо, що важливим $€$ й сформованість ціннісних орієнтацій у майбутніх вчителів природничих спеціальностей, не лише професійного змісту, а й гуманістичного. Під розумінням гуманістичних ціннісних орієнтацій особистості маємо на увазі наявність гуманістичних цінностей. У ще вужчому значенні, важливим вважаємо, сформованість гуманістичних ціннісних орієнтацій майбугніх вчителів природничих дисциплін до природного середовища.

Зазначимо, що сучасні українські вчені, 


\section{КЛЮЧОВІ КОМПЕТЕНТНОСТІМАЙБУТНІХ ВЧИТЕЛІВПРИРОДНИЧИХ СПЕЦІАЛЬНОСТЕЙ ТАЇХ ВПЛИВ НА ФОРМУВАННЯ СВІТОГЛЯДНИХ ОРІЄНТИРІВ СУЧАСНОӤ СТУДЕНТСЬКОЇ МОЛОДІ}

Т. Байбара, Н. Бібік, О. Пометун, визначили ряд ключових компетентностей таких як: вміння вчитися, здобувати необхідні професійні знання, вміння та навички; бажання та готовність працювати у педагогічній сфері; усвідомлення зони свого найближчого розвитку, здатність до процесів самовдосконалення; важливість опанування нормами та еталонами обраної професії, необхідність збагачення професійного досвіду; оволодіння громадянською та загальнокультурною компетентністю та ін.. Очевидно, що основна увага надається адаптації та можливості реалізації фахівця в обраній професійній сфері $[2,13]$.

Аналізуючи окреслені підходи в педагогічній освіті для здійснення ефективної підготовки майбутніх педагогів, ми виявили, що в основі досліджень науковців I. Беха, О. Бондаревської та ін., особистісно орієнтований підхід передбачається як можливість розвитку i саморозвитку особистісних якостей особистості на основі загальнолюдських цінностей $[1,3]$. В контексті особистісно-орієнтованого підходу, вчений І. Бех пропонує втілювати гуманістичні положення щодо особистісного зростання та самоствердження людини [1].

На думку науковців С. Вітвіцької, І. Кучинської аксіологічний підхід у розв'язанні глобальних проблем вищої освіти передбачає передусім виховання гуманістичного типу особистості студента. Найважливішим критерієм гуманізації вищої освіти стають не стільки набуті знання, уміння та навички, скільки усвідомлення й прийняття кожним студентом гуманістичних ідеалів, прагнення до постійного самовдосконалення [4].

Вчені Н. Борисенко, Н. Бібік, підкреслюють, що компетентнісний підхід в контексті сучасної педагогічної освіти передбачає не лише пасивне накопичення знань, а й наголошує на практичній реалізації отриманих умінь та навичок, ефективно застосовувати новітні інформаційні технології в професійній діяльності [2,3].

Що ж до процесу підготовки вчителів природничих спеціальностей, увага нашого дослідження зосереджена на наявності таких складових фахових професійних компетентностей, як природознавча та екологічна, за рахунок яких $\epsilon$ можливим поглиблення розуміння студентами суті гуманістичних цінностей, що в свою чергу сприятиме формуванню гуманістичних ціннісних орієнтацій. Адже, майбутні педагоги повинні оволодіти сформованою цілісною особистісною сферою, складовими якої є особисті ціннісні орієнтації, професійна готовність, сформована фаховими компетентностями, та реалізація відповідної діяльності.

Вважаємо за доцільне акцентувати увагу на тому, що у своїх дослідженнях, сучасний науковець Ю. Линник визначив професійну компетентність вчителів природничих спеціальностей, як закономірний та цілеспрямований процес якісних змін у системі професійних та особистісних якостей, інтересів, схильностей та мотивів, психолого-педагогічних знань, навичок; складовими якої є потребово-мотиваційний, когнітивний, діяльнісний та особистіснорефлексивний компоненти [6].

На думку педагога Н. Борисенко природознавча компетентність - компетенція у дії, виявляється у здатності студента застосовувати набуті знання, вміння і навички у різних видах екологічної діяльності, та спроможності організовувати процес навчання та виховання на екологічних засадах [3].

Науковець О. Ліба природознавчукомпетентність визначає як складову предметної компетентності, що визначається формуванням в учнів здатності розв'язувати доступні соціальні та особистісні значущі практичні та пізнавальні проблемні задачі, пов'язані з реальними об'єктами природи у сфері відносин “людина-природа" [5].

За результатами досліджень педагогів С. Левків, В. Маршицької, О. Колоньокової, екологічна компетентність $€$ результатом набуття і освоєння первинності законів природи по відношенню до соціальних законів, розуміння взаємної залежності та впливу суспільства i природи власної відповідальності за екологічні проблеми не лише свого регіону проживання, а й світу загалом; поєднання когнітивного, емоційноціннісного та практичного компонентів в інтегральному розвитку особистості.

3 ціллю визначення змісту професійної підготовки майбутніх вчителів природних спеціальностей у контексті формування гуманістично-ціннісних орієнтирів ми проаналізували освітньо-професійні програми підготовки бакалаврів: спеціальності 014 Середня освіта (Біологія та здоров'я людини) з додатковою предметною спеціальністю "Географія"; спеціальності 014 Середня освіта (Географія) 3 додатковою предметною спеціальністю “Біологія"; спеціальності 101 "Екологія". Та перелік фахових компетентностей підготовки магістрів: спеціальності 014 Середня освіта (Біологія та здоров'я людини); спеціальності 014 Середня освіта (Географія) та спеціальності 101 Екологія [7 - 12].

Опрацювавши освітньо-професійні програми 


\section{КЛЮЧОВІ КОМПЕТЕНТНОСТІМАЙБУТНІХ ВЧИТЕЛІВПРИРОДНИЧИХ СПЕЦАЛЬНОСТЕЙ ТӒ̈Х}

ВПЛИВ НА ФОРМУВАННЯ СВІТОГЛЯДНИХ ОРІЕНТИРІВ СУЧАСНОӤ СТУДЕНТСЬКОЇ МОЛОДІ

зазначених спеціальностей, ми виявили, що перелік компетентностей для підготовки студентів за рівнями бакалавр та магістр не відрізняються. Натомість, різниця полягає в спеціальних фахових компетентностях конкретної спеціальності. Перший (бакалаврський) рівень вищої освіти відповідає сьомому рівню Національної рамки кваліфікацій і передбачає здобуття особою теоретичних знань та практичних умінь і навичок, достатніх для успішного виконання професійних обов' язків за обраною спеціальністю.

Нижче зазначені компетентності є загальним для усіх виділених нами спеціальностей. Так, до переліку компетентностей першого (бакалаврського) рівня вищої освіти усіх зазначених спеціальностей майбутніх вчителів природничих дисциплін належать:

1.Інтегральна компетентність - здатність розв'язувати завдання в освітній діяльності, що вимагає застосування теоретичних знань та практичних умінь, в педагогічних умовах навчально-виховного процесу.

2.Загальні компетентності - здатність до здійснення навчальної та професійної діяльності. Включає здатність діяти на основі етичних міркувань, соціально-відповідально та свідомо.

Оскільки предметом нашого дослідження $є$ формування гуманістичних цінностей в навчально-виховному процесі, то серед ряду перелічених фахових компетентностей в освітньопрофесійній програмі спеціальності “Біологія", розглянемо саме ті пріоритетні спеціальнопредметні компетентності, які передбачають таку можливість.

Структура ключових фахових компетентностей майбутніх вчителів спеціальності 014 Середня освіта (Біологія та здоров'я людини) з додатковою предметною спеціальністю “Географія” включає здатність: розкривати загальні основи біологічної науки, аналізувати досягнення в біології; здатність формуванню в учнів природничо-наукової картини світу на базі міжпредметних зв'язків та розуміння суті стратегії сталого розвитку людства [7].

Серед ряду перелічених фахових компетентностей спеціальності 014 Середня освіта (Географія) 3 додатковою предметною спеціальністю “Біологія”, розглянемо наступні встановлені фахові компетентності, які на нашу думку необхідні для можливості формування гуманістичних цінностей у студентів. Такими $€$ здатність: встановлювати значення України в сучасному світовому географічному положенні; розуміти особливості геопросторової організації природи, населення держави, усвідомлювати студентами сутності взаємозв'язків між природним середовищем та людиною, розуміння особливостей фізико-географічних об'єктів у геосферах, аналізувати взаємозв'язки у ландшафтах та біогеоценозах [9].

Перелік виділених фахових компетентностей першого (бакалаврського) рівня вищої освіти спеціальності 101 “Екологія” передбачає здатність: вирішувати питання збалансованого співіснування людини і природи, застосовувати набуті знання при оцінюванні якості та розробці природоохоронної діяльності водних ресурсів, атмосферного повітря; обгрунтування заходів спрямованих на збереження ландшафтнобіологічного різноманіття та формування екологічної мережі; здатність виявляти джерела господарської діяльності та оцінювати її вплив на довкілля; використовувати сучасну систему нормативів для оцінки та регулювання антропогенного навантаження на навколишне середовище; застосовувати економічні механізми використання, охорони та відтворення природних ресурсів, використання знань та практичних навичок щодо управління та поводження 3 відходами виробництва та споживання для обмеження негативного техногенного впливу на стан довкілля [11].

Розглянемо фахові компетентності, які представлені в переліку освітньо-професійної підготовки студентів другого (магістерського) рівня вищої освіти. Зазначена освітньо-професійна програма підготовки магістра включає поглиблену фундаментальну, гуманітарну, соціальноекономічну, психолого-педагогічну, спеціальну та науково-практичну підготовку.

Ключові фахові компетентності спеціальності 014 Середня освіта “Біологія то здоров'я людини" передбачають оволодіння студентами здатністю: забезпечення збереження біорізноманіття та управління природокористуванням, а також вміння застосовувати для формування світоглядної позиції основні сучасні положення біологічних наук стосовно походження, розвитку, будови і процесів життєдіяльності живих організмів [8].

За спеціальністю 014 Середня освіта "Географія", передбачається оволодіння наступними фаховими компетентностями: використання сучасних новітніх технологій ГІС 3 метою розв'язання наукових і прикладних задач 3 моніторингу геоекологічних ситуацій; застосування знань з регіоналізації природних територіальних комплексів для потреб просторового планування господарства, охорони природи та раціонального використання природних ресурсів, соціально-економічних аспектів природокористування і природоохоронного 


\section{КЛЮЧОВІ КОМПЕТЕНТНОСТІМАЙБУТНІХ ВЧИТЕЛІВПРИРОДНИЧИХ СПЕЦІАЛЬНОСТЕЙ ТАЇХ}

ВПЛИВ НА ФОРМУВАННЯ СВІТОГЛЯДНИХ ОРІЕНТИРІВ СУЧАСНОЇ СТУДЕНТСЬКОЇ МОЛОДІ

законодавства, а також еколого-економічного світогляду; здатність оволодіння знаннями про основні проблеми сучасної географії в контексті концепції сталого розвитку, наукових підходів щодо раціонального використання і охорони природних ресурсів, методології і методів географічної науки [10].

Спеціальність 101 “Екологія” другого (магістерського) рівня вищої освіти передбачає набуття студентами наступних фахових компетентностей, таких як здатність: застосовувати теоретичні основи, інструменти та методи системного аналізу якості навколишнього середовища; використовувати сучасні методи оцінки стану і якості природних та антропогенноприродних екосистем; оволодіння знаннями перспектив вирішення екологічних проблем в регіонах; забезпечувати екологічну безпеку та умови стійкого розвитку, розв'язувати задачі, направлені на зменшення антропогенного впливу на екосистеми; здатність застосовувати засади i принципи державної політики у сфері охорони довкілля та раціонального природокористування елементи біосфери тих чи інших техногенних факторів [12].

Здійсненний аналіз фахових компетентностей майбутніх вчителів природничих дисциплін, дозволив визначити наявність таких компетентностей, як природознавча та екологічна, що тісно переплетені та доповнюють одна одну. Оволодіння природознавчою та екологічною компетентностями, в контексті фахових, передбачається під час вивчення біологічних, географічних та екологічних наук, зокрема, оволодіння знаннями, вміннями та навичкам, що передбачені у програмах навчальних дисциплін відповідно до навчальних планів.

Вважаємо, що охарактеризовані компетентності додатково підкреслюють важливість поєднання процесів формування фахових компетентностей умайбутніх вчителів природничих спеціальностей 3 гуманістичним ціннісним ставленням до навколишнього середовища.

Висновки. Оскільки сучасні науковопедагогічні розвідки, обгрунтовують важливість введення до професійних компетентностей особистісних та мотиваційних якостей майбутніх педагогів, вважаємо що формування гуманістичних цінностей займає вагоме місце в професійному становленні майбутніх вчителів природничих спеціальностей. Адже, перший (бакалаврський) та другий (магістерський) рівні вищої освіти передбачають здатність студентів здійснювати професійну діяльність, та поширювати біологічні, географічні та екологічні знання в площину шкільної освіти, або вищої освіти, вважаємо, що додаткова сформованість особистісних гуманістичних ціннісних орієнтирів майбутніх вчителів, буде проектуватися вже на майбутніх учнів (студентів), що в свою чергу сприятиме у останніх формуванню власних гуманістичних цінностей.

Таким чином, усі зазначені пріоритетні компетентності уможливлюють якість і ефективність реалізації формування гуманістичноціннісної орієнтації, як у майбутніх вчителів (викладачів) географії, так і в майбутніх учнів (студентів).

\section{ЛІТЕРАТУРА}

1. Бех І. Д. Особистість у просторі духовного розвитку : навч. посіб. Київ, 2012. $256 \mathrm{c}$.

2. Бібік Н. М. Компетентнісний підхід: рефлексивний аналіз застосування. Компетентнісний підхід у сучасній освіті: світовий досвід та украӥнські перспективи: Бібліотека освітньої політики. Київ, 2004. C. 47-52.

3. Борисенко Н. М. Педагогічні умови формування природознавчої компетентності майбутнього вихователя дошкільного закладу. Збірник наукових праць Херсонського державного університету. Педагогічні науки. 2014. Вип. 65. С. 279-285. URL: http:/ /nbuv.gov.ua/UJRN/znppn

4. Кучинська I. О. Виховання духовних цінностей дітей і молоді у творчій спадщині Івана Огієнка. Кам'янець-Подільський, 2002.104 с.

5. Ліба. О. Компетентнісний підхід як концептуальна основа підготовки майбутніх учителів початкової школи. Молодь і ринок. 2018. №2 (157). С. 28-33

6. Линник Ю. Структура та способи оцінки рівня розвитку професійної компетентності вчителів природничих спеціальностей. Гуманітарний вісник Державного вищого навчального закладу "ПереяславХмельницький державний педагогічний університет імені Г. С. Сковороди". Педагогіка. Психологія. Філософія. 2013. № 28(2). С. 170-177.

7. Освітньо-професійна програма "Біологія" 3 додатковою предметною спеціальністю "Географія" першого (бакалаврського) рівня вищої освіти за спеціальністю 014 Середня освіта (Біологія та здоров'я людини) / Кам'янець-Подільський національний університет імені І. Огієнка, Кам'янець-Подільський, $2018.29 \mathrm{c}$.

8. Освітньо-професійна програма “Біологія” другого (магістерського) рівня вищої освіти за спеціальністю 014 Середня освіта (Біологія та здоров'я людини) / Кам'янець-Подільський національний університет імені I. Огієнка, Кам'янець-Подільськ, 2018. 17 с.

9. Освітньо-професійна програма "Географія" першого (бакалаврського) рівня вищої освіти за спеціальністю 014 Середня освіта (Географія) додатковою предметною спеціальністю "Біологія" / Кам'янець-Подільський національний університет імені I. Огієнка, Кам'янець-Подільський, 2018. 19 с 


\section{КЛЮЧОВІ КОМПЕТЕНТНОСТІМАЙБУТНІХ ВЧИТЕЛІВПРИРОДНИЧИХ СПЕЦАЛЬНОСТЕЙ ТАЇХ ВПЛИВ НА ФОРМУВАННЯ СВІТОГЛЯДНИХ ОРІЕНТИРІВ СУЧАСНОЇ СТУДЕНТСЫКОЇ МОЛОДІ}

10. Освітньо-професійна програма “Географія” другого (магістерського) рівня вищої освіти за спеціальністю 014 Середня освіта (Географія) / Кам’янець-Подільський національний університет імені І. Огієнка, Кам’янець-Подільський, 2018. 13 с.

11. Освітньо-професійна програма "Екологія" першого (бакалаврського) рівня вищої освіти за спеціальністю 101 Екологія / Кам'янець-Подільський національний університет імені І. Огієнка, Кам' янецьПодільський, 2018. 19 с.

12. Освітньо-професійна програма "Екологія" другого (магістерського) рівня вищої освіти за спеціальністю 101 Екологія / Кам'янець-Подільський національний університет імені І. Огієнка, Кам'янецьПодільський, 2018. 15 с.

13. Пометун О. I. Формування громадянської компетентності : погляд з позиції сучасної педагогічної науки. Вісник програм шкільних обмінів. 2005. № 23. C. $18-20$.

\section{REFERENCES}

1. Bekh, I. D. (2012). Osobystist u prostori dukhovnoho rozvytku : navch. posib [Personality in the space of spiritual development: teach. manual]. Kyiv, 256 p. [in Ukrainian].

2. Bibik, N. M. (2004). Kompetentnisnyi pidkhid: refleksyvnyi analiz zastosuvannia [Competency Approach: Reflexive Application Analysis]. Competency Approach in Modern Education: World Experience and Ukrainian Prospects: Library for Educational Policy. Kyiv,pp.47-52. [in Ukrainian].

3. Borysenko, N. M. (2014). Pedahohichni umovy formuvannia pryrodoznavchoi kompetentnosti maibutnoho vykhovatelia doshkilnoho zakladu [Pedagogical conditions for the formation of natural science competence of the future teacher of a preschool institution]. Collection of scientific works Kherson State University. Pedagogical sciences. Issue 65, pp. 279-285. [in Ukrainian].

4. Kuchynska, I. O. (2002). Vykhovannia dukhovnykh tsinnostei ditei $i$ molodi u tvorchii spadshchyni Ivana Ohiienka [Education of spiritual values of children and youth in the creative heritage of Ivan Ogienko]. KamianetsPodilsky, 104 p. [in Ukrainian].

5. Liba, O. (2018). Kompetentnisnyi pidkhid yak kontseptualna osnova pidhotovky maibutnikh uchyteliv pochatkovoi shkoly [Competency approach as a conceptual basis for the preparation of future teachers of elementary school]. Youth and market. No. 2 (157), pp.2833. [in Ukrainian].

6. Lynnyk, Yu. (2013). Struktura ta sposoby otsinky rivnia rozvytku profesiinoi kompetentnosti vchyteliv pryrodnychykh spetsialnostei [Structure and methods of estimation of the level of development of professional competence of teachers of natural sciences]. Humanitarian Bulletin of the State Higher Educational Institution "Pereyaslav-Khmelnytsky State Pedagogical University named after G. S. Skovoroda”. Pedagogy. Psychology. Philosophy. No. 28 (2),pp. 170-177. [in Ukrainian].

7. Osvitno-profesiina prohrama "Biolohiia” $z$ dodatkovoiu predmetnoiu spetsialnistiu "Heohrafiia' pershoho (bakalavrskoho) rivnia vyshchoi osvity za spetsialnistiu 014 Serednia osvita (Biolohiia ta zdorovia liudyny) [Educational-professional program "Biology" with an additional subject specialty "Geography" of the first (Bachelor) level of higher education in the specialty 014 Secondary education (Biology and human health)]. Kamianets-Podilsky National University named after I. Ogienko. Kamianets-Podilsky. 2018. 29 p. [in Ukrainian].

8. Osvitno-profesiina prohrama "Biolohiia” druhoho (mahisterskoho) rivnia vyshchoi osvity za spetsialnistiu 014 Serednia osvita (Biolohiia ta zdorovia liudyny) [Educational and professional program "Biology" of the second (master's) level of higher education in the specialty 014 Secondary education (Biology and human health)]. Kamianets-Podilsky National University named after I. Ogienko, Kamianets-Podilsky. 2018. 17 p. [in Ukrainian].

9. Osvitno-profesiina prohrama "Heohrafiia" pershoho (bakalavrskoho) rivnia vyshchoi osvity za spetsialnistiu 014 Serednia osvita (Heohrafiia) z dodatkovoiu predmetnoiu spetsialnistiu "Biolohiia" [Educational and professional program "Geography" of the first (Bachelor) level of higher education in the specialty 014 Secondary education (Geography) with an additional subject specialization "Biology"]. KamianetsPodilsky National University named after I. Ogienko. Kamianets-Podilsky. 2018. 19 p. [in Ukrainian].

10. Osvitno-profesiina prohrama "Heohrafiia" druhoho (mahisterskoho) rivnia vyshchoi osvity za spetsialnistiu 014 Serednia osvita (Heohrafiia) [Educational-professional program "Geography" of the second (master's) level of higher education in the specialty 014 Secondary education (Geography). KamianetsPodilsky National University named after I. Ogienko. Kamianets-Podilsky. 2018. 13 p. [in Ukrainian].

11. Osvitno-profesiina prohrama "Ekolohiia" pershoho (bakalavrskoho) rivnia vyshchoi osvity za spetsialnistiu 101 Ekolohiia [Educational and professional program "Ecology" of the first (Bachelor) level of higher education in the specialty 101 Ecology]. Kamianets-Podilsky National University named after I. Ogienko, Kamianets-Podilsky. 2018. 19 p. [in Ukrainian].

12. Osvitno-profesiina prohrama "Ekolohiia" druhoho (mahisterskoho) rivnia vyshchoi osvity za spetsialnistiu 101 Ekolohiia [Educational-professional program "Ecology" of the second (master's) level of higher education by specialty 101 Ecology]. Kamianets-Podilsky National University named after I. Ogienko. KamianetsPodilsky. 2018. 15 p. [in Ukrainian].

13. Pometun, O. (2005). Formuvannia hromadianskoi kompetentnosti : pohliad z pozytsii suchasnoi pedahohichnoi nauky [Formation of civic competence: a view from the standpoint of modern pedagogical science]. Bulletin of School Exchange Programs. No. 23, pp. 1820. [in Ukrainian].

Стаття надійшла до редакції 29.03.2019 